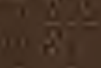

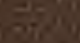

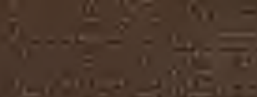

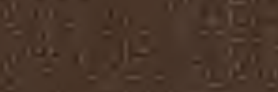

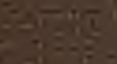

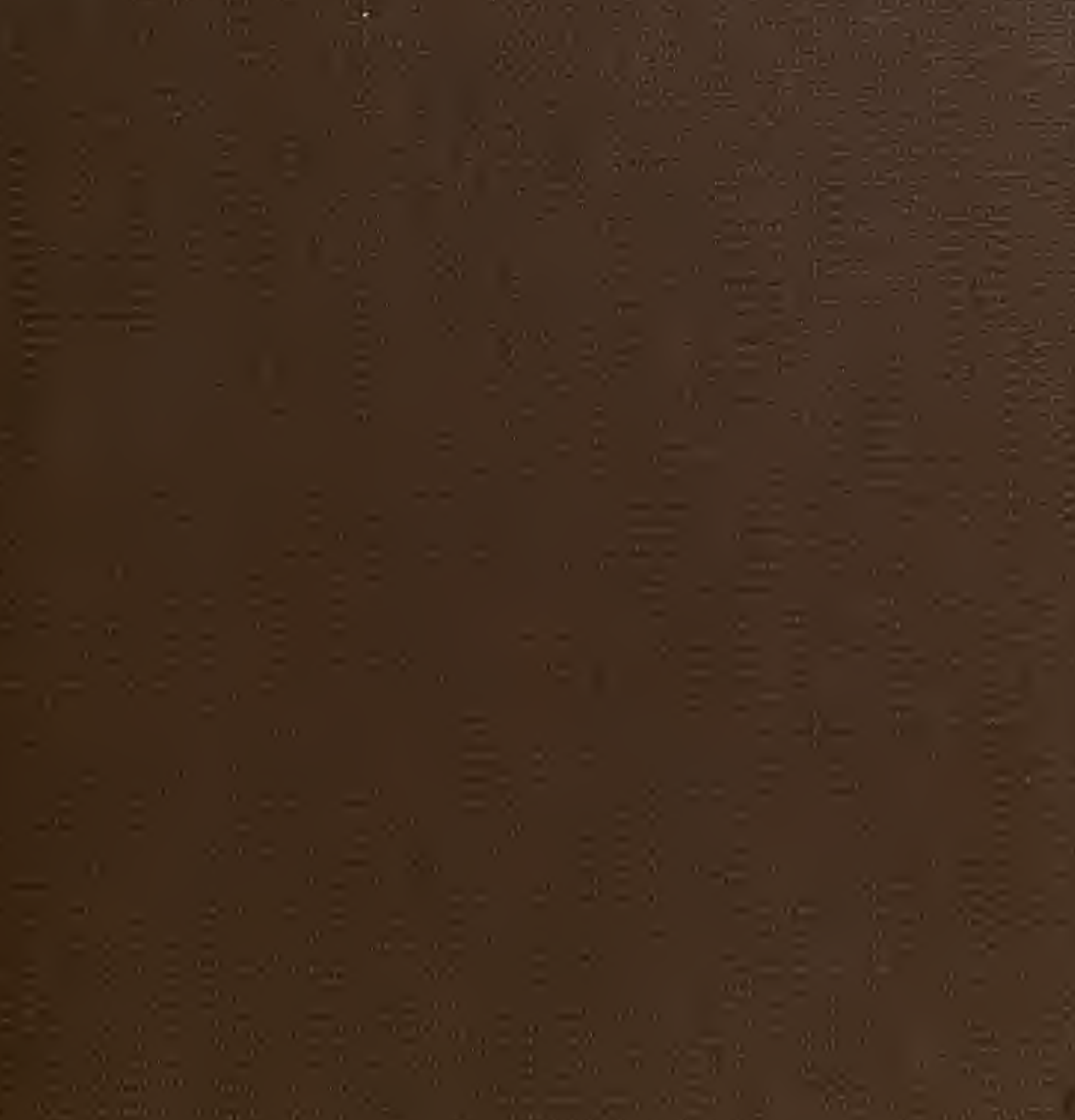

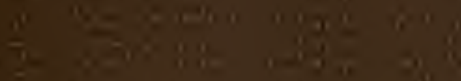

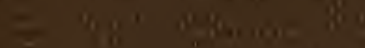

19:

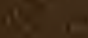

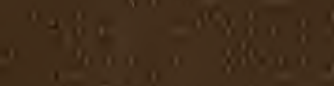

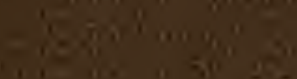

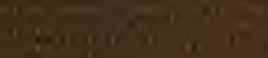

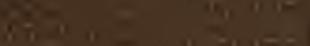

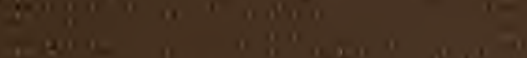
$+x^{2}=$

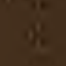

$\min 2$

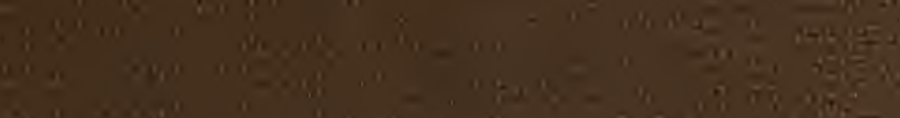

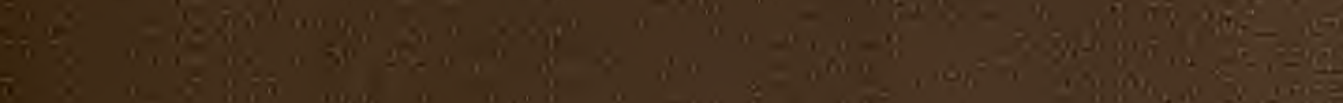

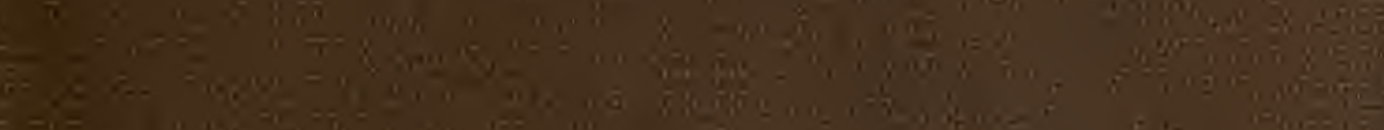

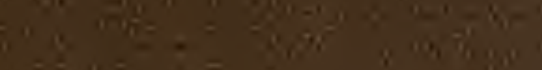




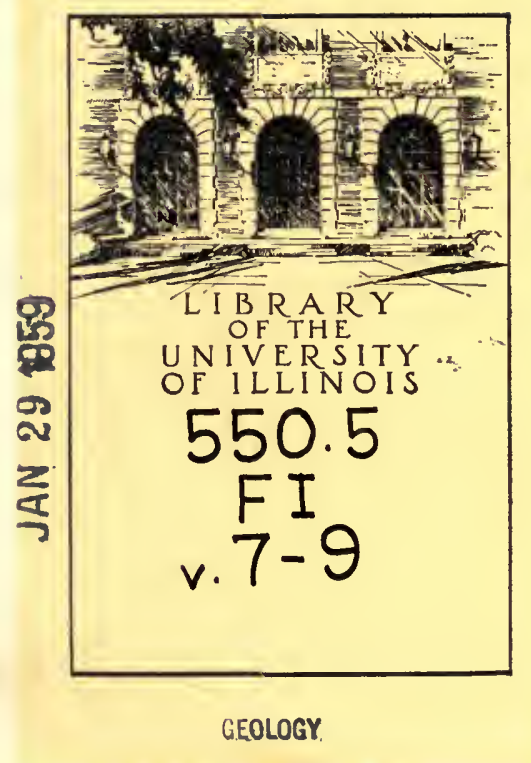

\author{
UNIVERSITY OF \\ ILLINOIS LIBRARY \\ AT URBANA-CHAMPAIGN \\ GEOLOGY
}


Return this book on or before the Latest Date stamped below.

GEOLOGY LIBRARY

University of Illinois Library

MAY $2 ? 1965$

MAY 91966

ОСТ 031994

OCT 081994

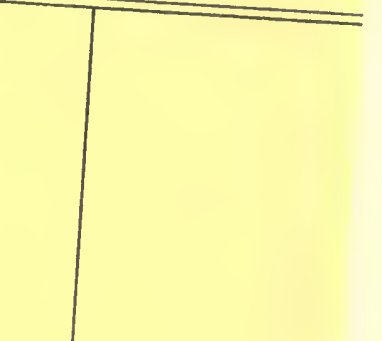







\title{
GEOLOGICAL SERIES
}

OF

FIELD MUSEUM OF NATURAL HISTORY

\section{A NEW FOSSIL ALLIGATOR FROM NEBRASKA}

\author{
BY KARL P. SCHMIDT \\ Chief Curator, Department of Zoology
}

The paleontological expedition of Field Museum of Natural History in 1940, conducted by Mr. Paul O. McGrew, Assistant Curator of Paleontology, explored various deposits in Nebraska, principally of Miocene age. Mr. McGrew was accompanied by Ellsworth Shaw and my son, John M. Schmidt, as volunteer assistants. The work in Nebraska was concluded by a stay of several weeks at the Aletomeryx gracilis quarry southeast of Gordon, in Cherry County, which is known from the collections of R. S. Lull in 1914.

Soon after the arrival of the party at this quarry, my son had the good fortune to uncover the skull of a fossil crocodilian. The skull seemed to be of more than usual interest for its extremely shortened form and curious shape. On the return of the party from the field, this specimen was prepared by Mr. James H. Quinn of the Museum's paleontological laboratory, and turned over to me for study by Mr. Elmer S. Riggs, Curator of Paleontology, at whose suggestion I have for some time dealt with fossil specimens of the living orders of reptiles. I am indebted to him for the privilege of reporting upon this specimen, and to Messrs. McGrew, Bryan Patterson, and Quinn for aid in interpreting the distortion undergone by the specimen in the course of fossilization. The drawings representing our restoration of the skull were prepared by Mr. John J. Janecek of the Museum's staff. I take pleasure in naming the new form for my friend and colleague, Paul O. McGrew, leader of the expedition.

\section{Order Crocodilia}

\section{Suborder Eusuchia}

Family Alligatoridae

Alligator mcgrewi, sp. nov.

Holotype.-F.M. No. P26242, a nearly complete but somewhat crushed and distorted skull, apparently of a half-grown individual, 


\section{Field Museum of Natural History-Geology, Vol. 8}

with the nearly complete rami of the lower jaw. Collected by John M. Schmidt.

Referred specimen.-F.M. No. P26281, two fragments of maxillary, a few associated teeth, and other small bone fragments. Collected by Paul O. McGrew.

Horizon and type locality.-Marseland Formation, uppermost Lower Miocene, from the Aletomeryx gracilis quarry (Lull, 1914), near the mouth of Antelope Creek, southeast of Gordon, Cherry County, Nebraska.

Diagnosis.-An Alligator with snout wider than long, a bony bridge through the external nares, which are broad and outwardly reflected, no ante-orbital or frontal ridges, and upper and lower teeth respectively 18 and 17 . Well distinguished from Alligator thomsoni by its unridged ante-orbital region and broader snout and apparently by a complete bony narial bridge; more closely allied to Alligator prenasalis, from which it differs in its much broader snout, broader cranial table, fewer teeth, and narial bridge.

Description of type.-The skull is short and broad, the snout much wider than its length (8:7); the outer surfaces of the skull are moderately but completely and uniformly pitted; most of the bones of the skull are relatively wide and short, in association with its general form; there is no transverse frontal ridge, and the anterior borders of orbits are not raised into ridges; the top of the cranial table is flat, and the supra-temporal fossae are wider than the outer bars of bone, and a little wider than the middle parietal bar. The external narial aperture is large, with its smooth inner surface reflected so much outward as to form a distinct bordering ridge with a corresponding lateral pit below it on the outer face of the premaxilla; the nasals are very broad and sharply truncate anteriorly; prolongations of the nasals to form the narial bridge arise abruptly, their anterior ends being obliquely truncate from above downward and backward; this truncate surface is apparently sutural.

The palatal surface is much broken and distorted; the pterygoids are short and oblique, and not inflated; the internal nares are broken away, but their posterior position is indicated by a raised bordering ridge preserved on one side; the palatines are apparently not at all inflated.

The dentition, subject to possible misinterpretation, consists of 13 maxillary and 5 premaxillary teeth on each side. The anterior maxillary teeth are pointed, the fourth largest, and first minute; the large fourth maxillary tooth is somewhat recurved, and smooth 


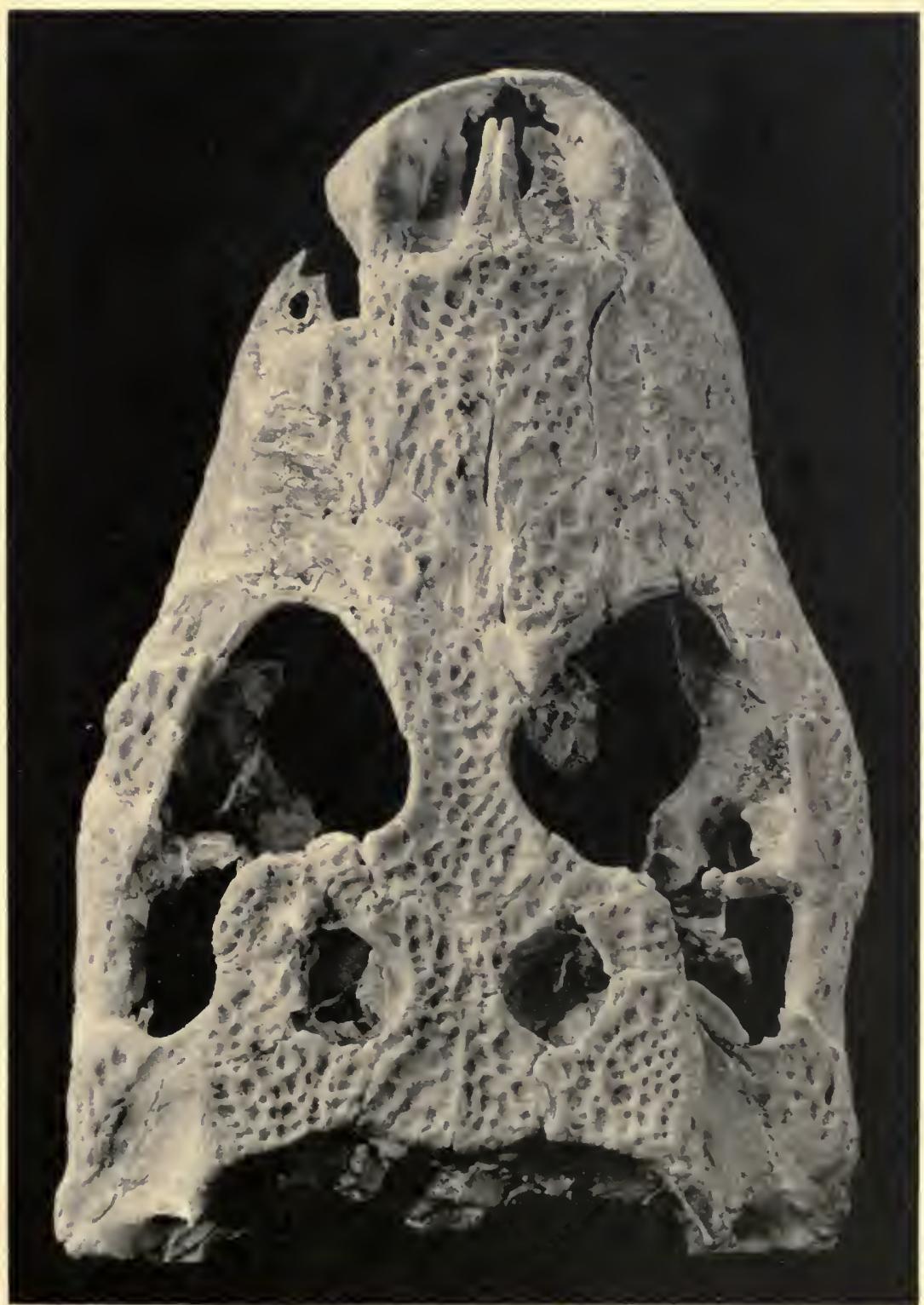

FIG. 10. Dorsal view of skull of Alligator megrewi (photograph); natural size. 
except for a ridge on its anterior borders, and the succeeding teeth are small, compressed, and striate, the posterior ones with rounded low crowns. The upper tooth row strongly overhangs the lower, and deep pits for the reception of the enlarged fourth lower tooth of each side are present at the premaxillo-maxillary suture; there are shallower pits opposite the fifth to seventh maxillary teeth for the enlarged twelfth and thirteenth lower teeth.

Rami of the lower jaw separated, both with the articular missing; tooth row short, teeth in the more complete right ramus 17 , the fourth and thirteenth greatly enlarged, the sixth to eleventh extremely small. A shallow groove extends backward from the last tooth, with no trace of alveoli. The symphysis extends to the level of the eighth tooth. The splenial, its anterior end broken away for about a centimeter, seems to have entered the symphysis, though only narrowly.

\section{MEASUREMENTS}

(In millimeters)

Length of skull, premaxillaries to posterior border of cranial table... . . . . 138.4

Length of skull, premaxillaries to occipital condyle . . . . . . . . . . 145.2

Width of skull at condyles........................ 96.4

Length of snout (from anterior border of orbits) ............. 71.4

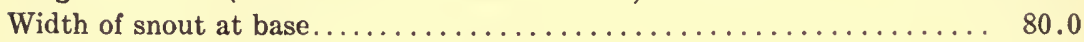

Width of snout at fourth maxillary tooth ................... 62.5

Width of cranial table anteriorly....................... 54.2

Width of cranial table posteriorly....................... 60.1

Pterygoid width.............................. 65.7

Width of frontal between orbits..................... 12.1

Width of parietal between supra-temporal fenestrae. . . . . . . . . 11.9

Width of fourth premaxillary tooth ..................... 4.1

Width of fourth maxillary tooth $\ldots \ldots \ldots \ldots \ldots \ldots \ldots \ldots \ldots \ldots \ldots, 6.8$

I interpret the small skull above described as that of an individual at least more than half grown. Compared with skulls of Alligator mississipiensis, the fossil skull is as well pitted as a skull $350 \mathrm{~mm}$. in length. A skull of Alligator sinensis (U.M.M.Z. 61446), available for comparison through the courtesy of Mrs. Helen T. Gaige of the Museum of Zoology at the University of Michigan, measures $200 \mathrm{~mm}$. from snout to posterior border of cranial table, and evidently is that of a mature animal. This skull is little, if at all, more rugose than the skull of the new fossil species. I conclude that our skull represents a specimen, a meter or more in length, of a dwarf species of crocodilian in which adults measured about two meters.

The sutural surface of the anterior border of the nasal projections indicates their union with backwardly directed processes of 


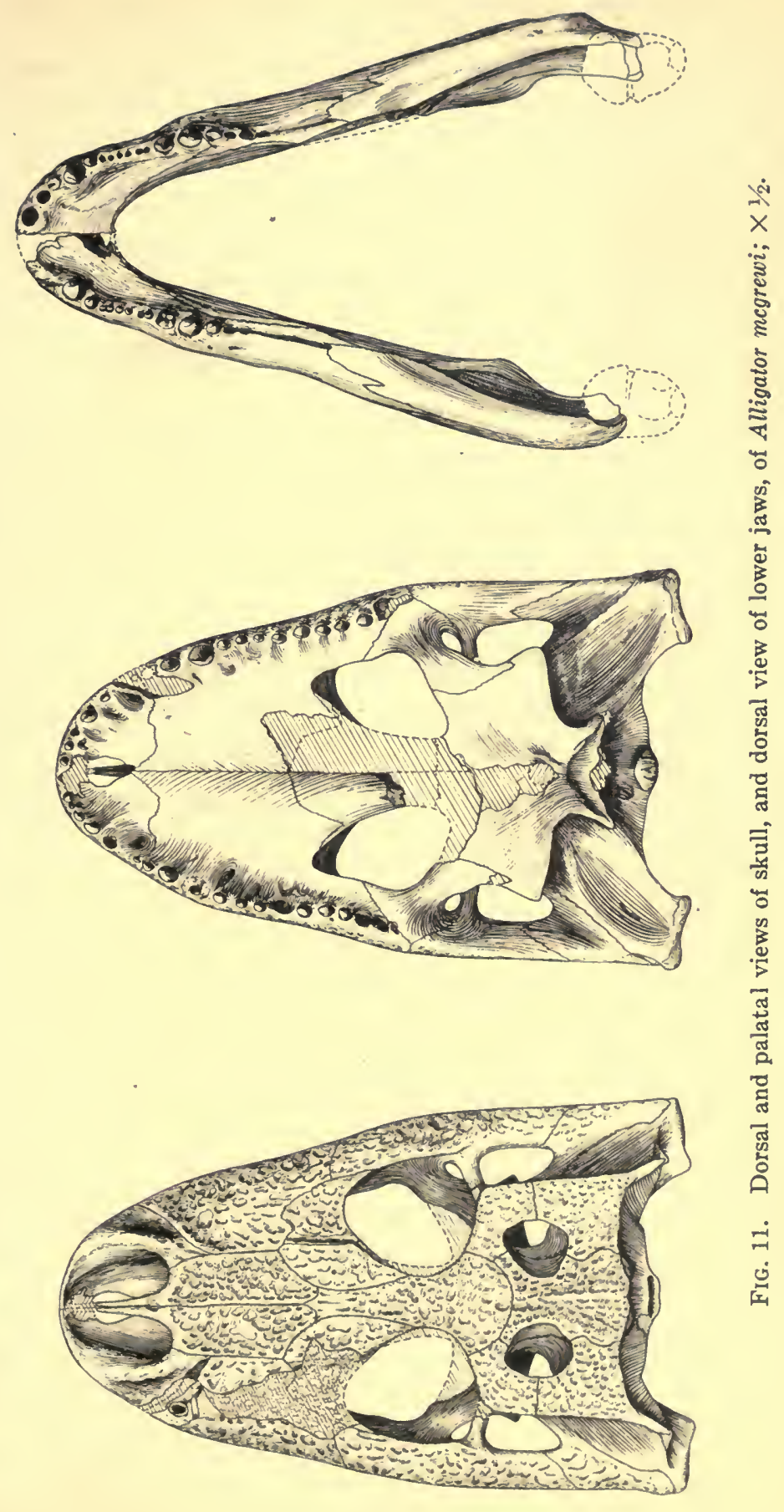


the premaxillaries. The narial bridge does not appear to have been complete in prenasalis or thomsoni. The extreme shortness of the snout in Alligator megrewi clearly removes it from the direct ancestry of either A. sinensis or A. mississipiensis. It is distinguished further by the shortness of its tooth rows, and reduced number of teeth.

The length of the mandibular suture and the general form of the lower jaws exhibit close agreement with Alligator thomsoni, so much so that it is surprising to find the new species so distinct in other characters. The entry of the splenial into the symphysis seems to be about equal to that in Alligator prenasalis.

Discussion.-If Mook is correct in his reference of Alligator thomsoni, from the Snake Creek beds south of Agate, Nebraska, to the Pliocene (Mook, 1932, p. 41), Alligator mcgrewi helps to fill the Miocene gap in the history of the genus Alligator. The close resemblance of Alligator thomsoni to the living $A$. sinensis leaves prenasalis and mcgrewi somewhat isolated. It seems reasonable to suggest that Caimanoidea vischeri Mehl and Allognathosuchus riggsi Patterson be included in the genus Alligator in this broad sense. The contrary view appears to require the reference of prenasalis and megrewi to Caimanoidea; but since mcgrewi links the Oligocene forms with the Recent in its bony narial bridge, and resembles thomsoni in certain other characters, and pending more comprehensive comparative study of the forms in question, I much prefer to refer all of these Tertiary forms to the genus Alligator.

\section{REFERENCES}

LULL, R. S.

1920. New Tertiary Artiodactyles. Amer. Jour. Sci., (V) 150, pp. 83-130, pl. 1.

MEHL, G.

1916. Caimanoidea vischeri, a New Crocodilian from the Oligocene of South Dakota. Jour. Geol., 24, pp. 47-56, figs. 1-4.

Моок, C.

1923. A New Species of Alligator from the Snake Creek Beds. Amer. Mus. Nov., 73, pp. 1-13, figs. 1-5.

1925. The Ancestry of the Alligators. Nat. Hist., 25, pp. 407-408, 2 figs.

1932. A Study of the Osteology of Alligator prenasalis (Loomis). Bull. Mus.

Comp. Zool., 74, pp. 19-41, figs. 1-10, 1 table, pls. 1-3.

PATTERSON, BRyan

1931. Occurrence of the Alligatorid Genus Allognathosuchus in the Lower Oligocene. Field Mus. Nat. Hist., Geol. Ser., 4, pp. 221-226, pl. 41. 






UNIVERSITY OF ILLINOIS-URBANA

$550.5 \mathrm{FI}$

FIELDIANA, GEOLOGY CHGO

7-9 1937/45

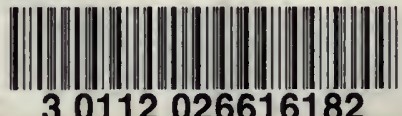

